\title{
Social Anxiety, Internet Addiction and Attention Deficit/ Hyperactivity Disorder in Adolescence
}

\begin{abstract}
Melek Gözde Luş ${ }^{1}$
Abstract: The aim of the present study was to evaluate the relationship between Internet addiction (IA), Social Anxiety Disorder (SAD) and Attention deficit/hyperactivity disorder (ADHD) among adolescents. The study consisted of 100 children aged 12-16; who were diagnosed with ADHD. A total of 100 adolescents completed the Young Internet Addiction Scale (YIAS) and Metacognitive Awareness Inventory for Children (Jr. MAI) -B form.Clinicians administered the Child Anxiety Sensitivity Index (CASI) and the Social Anxiety Scale for Children-Revised (SASC-R). Teachers and parents of the children completed the Conners' Rating Scales. The most important observation to emerge from the data comparison was that there was no statistically significant correlation between SASC-R and YIAS scores and there was no statistically significant correlation between YIAS and CASI scores. Contrary to expectations, in most of the measurements, there were no significant differences. The evidence from this study is incompatible with the idea that IA, and SAD are also related with the comorbid ADHD. We believe that our results may improve knowledge about the use of holistic perspective in the approach to IA and comorbid disorders
\end{abstract}

Key words: Attention Deficit/Hyperactivity Disorder, Internet Addiction, Adolescent, Comorbidity, Social Anxiety

\section{Ergenlerde Sosyal Anksiyete, İnternet Bağımlılığı ve Dikkat Eksikliği/ Hiperaktivite Bozukluğu}

Özet: Bu çalışmanın amacı, ergenler arasında İnternet bağımlılığı (IA), Sosyal Anksiyete Bozukluğu (SAD) ile Dikkat eksikliği / hiperaktivite bozukluğu (DEHB) arasındaki ilişkiyi değerlendirmektir. Çalışma grubu, 12-16 yaş arası DEHB tanısı konulan 100 çocuktan oluşmaktadır. Toplam 100 ergen, Young İnternet Bağımlılığı Ölçeğini (YIAS) ve Çocuklar İçin Metakognitif Farkındalık Envanteri'ni (Jr. MAI) -B doldurdu. Klinisyenler, Çocuk Anksiyetesi Duyarlılık Endeksi'ni (CASI) ve Gözden Geçirilmiş Çocuklar İçin Sosyal Anksiyete Ölçeğini (SASC-R) uygulamıştır. Çocukların öğretmenleri ve ebeveynleri, Conners Değerlendirme Ölçeklerini tamamlamıştır. Veri karşılaştırmalarından çıkan en önemli özlem, SASC-R ve YIAS skorları arasında istatistiksel olarak anlamlı bir ilişki olmadığı ve YIAS ve CASI skorları arasında istatistiksel olarak anlamlı bir ilişki olmadığıdır. Beklentilerin aksine, ölçümlerin çoğunda, önemli bir fark yoktu. Bu çalışmadan elde edilen kanıtlar IA ve SAD'nin aynı zamanda komorbid DEHB ile ilişkili olduğu fikri ile uyumlu değildir. Sonuçlarımızın IA ve eşlik eden bozukluklara bütünsel yaklaşım hakkındaki bilgileri artırabileceğine inanıyoruz.

Anahtar Kelimeler: Dikkat Eksikliği / Hiperaktivite Bozukluğu, İnternet Bağımlılığı, Ergen, Komorbidite, Sosyal Anksiyete

Uzm. Dr., University of Health Sciences, Haydarpaşa Numune Training and Research Hospital

Address of correspondence/Yazışma adresi: Uzm. Dr., Melek Gözde Luş, University of Health Sciences, Haydarpaşa Numune Training and Research Hospital, Department of Child and Adolescent Psychiatry, Istanbul, Turkey, E-mail: gozdelus@yahoo.com

Date of Received/Geliş Tarihi: 30.10.2019, Date of Revision/Düzeltme Tarihi: 02.11.2019, Date of Acceptance/Kabul Tarihi: 04.11.2019

Citing/ Referans Gösterimi: Luş, M.G. (2019). Social Anxiety, Internet Addiction and Attention Deficit/Hyperactivity Disorderin Adolescence. Kıbrıs Türk Psikiyatri ve Psikoloji Dergisi, 1(Özel Sayı.1): 53-55 doi:10.35365/ctjpp.19.special1.15 


\section{Introduction}

Problematic internet use or internet addiction (IA) are terms most commonly used when referring to loss of control over or maladaptive patterns of internet use leading to clinically significant impairment or distress (An et al.,2014;Xu et al., 2012).Studies suggest that overall prevalence of IA in adolescents ranges between $2 \%$ and $18 \%$ (Ge, Se, Zhang, 2014; Bahrainian and Khazaee, 2014).As it is known, there is significant association between IA and ADHD in adolescents (Yen et al., 2007) and untreated ADHD can be unfavorable for children, such as negative effect on normal development, failure in school success, and deterioration of social functioning. Beside this, approximately $25 \%$ to $50 \%$ of ADHD cases may also have a comorbid anxiety disorder (Bishop et al.,2019;Jarrett and Ollendick, 2008).As a consequence of Social Anxiety Disorder (SAD) in children with ADHD, social dysfunction gradually deteriorates and generally persists into adolescence, which is associated with worse outcomes including, but not limited to, substance use disorders and depressive disorders (Ruscio et al., 2008).Studies conducted to date show that, the presence of psychiatric comorbidities may have negative impact on psychosocial functioning and treatment outcome for IA. Based on this background, in the present study, we aimed to evaluate the association of IA and social anxiety in children with ADHD.

\section{Materials and Methods:}

The study consisted of 100 children aged 12-16; who were diagnosed with ADHD. A total of 100 adolescents completed the Young Internet Addiction Scale (YIAS) and Metacognitive Awareness Inventory for Children (Jr. MAI-B) form.Clinicians administered the Child Anxiety Sensitivity Index (CASI) and the Social Anxiety Scale for Children-Revised (SASC-R). Teachers and parents of the children completed the Conner's Rating Scales (teacher and parent form).

\section{Results}

A total of 100 children with ADHD with a mean age of $13.88 \pm 1.387$ (range: 12-16) years were included in the study; 36 were boys and 64 were girls. The most important observation to emerge from the data comparison was that there was no statistically significant correlation between SASC-R and YIAS scoresand there was no statistically significant correlation between YIAS and CASI scores. Contrary to expectations, in most of the measurements, there were no significant differences. The average YIAS score of ADHD group was 29.88. Descriptive statistics of scales scores and correlation of the scales are presented in Table 1 and 2.

Table 1. Descriptive Statistics of Scales Scores

\begin{tabular}{llllll} 
& N & Minimum & Maximum & Mean & Std. Deviation \\
\hline SASC-R & 100 & 18 & 81 & 38,98 & 12,820 \\
CASI & 100 & 2 & 52 & 42,35 & 7,530 \\
Conners t. & 100 & 6 & 75 & 30,83 & 13,758 \\
Conners p. & 100 & 17 & 104 & 43,99 & 15,682 \\
Jr. MAI -B & 100 & 20 & 83 & 37,65 & 13,335 \\
YIAS & 100 & 11 & 67 & 29,88 & 9,922 \\
Age & 100 & 12 & 16 & 13,88 & 1,387 \\
Valid N (listwise) & 100 & & & & \\
\hline
\end{tabular}

Table 2. Correlations

\begin{tabular}{|c|c|c|c|c|c|c|c|c|}
\hline & & SASC-R & CASI & Conners t. & Conners p & Jr. MAI-B & YIAS & Age \\
\hline \multirow[t]{3}{*}{ SASC-R } & Pearson Correlation & 1 &,- 077 &,- 142 & ,218(*) &,$- 269(* *)$ &, 057 & $\overline{-, 090}$ \\
\hline & Sig. (2-tailed) & &, 449 &, 160 &, 030 &, 007 &, 571 &, 374 \\
\hline & $\mathrm{N}$ & 100 & 100 & 100 & 100 & 100 & 100 & 100 \\
\hline \multirow{3}{*}{ CASI } & Pearson Correlation &,- 077 & 1 &, 123 &, 156 &, 022 &,- 094 &,- 058 \\
\hline & Sig. (2-tailed) &, 449 & &, 221 &, 121 &, 831 &, 351 & ,568 \\
\hline & $\mathrm{N}$ & 100 & 100 & 100 & 100 & 100 & 100 & 100 \\
\hline \multirow[t]{3}{*}{ Conners t. } & Pearson Correlation &,- 142 &, 123 & 1 &, $310(* *)$ &,- 169 &,- 049 & ,048 \\
\hline & Sig. (2-tailed) &, 160 &, 221 & &, 002 & ,093 &, 629 & ,634 \\
\hline & $\mathrm{N}$ & 100 & 100 & 100 & 100 & 100 & 100 & 100 \\
\hline \multirow[t]{3}{*}{ Conners p. } & Pearson Correlation & ,218(*) &, 156 &, $310(* *)$ & 1 &,$- 202(*)$ &,- 020 &,- 098 \\
\hline & Sig. (2-tailed) &, 030 &, 121 &, 002 & &, 043 &, 847 &, 330 \\
\hline & $\mathrm{N}$ & 100 & 100 & 100 & 100 & 100 & 100 & 100 \\
\hline \multirow[t]{3}{*}{ Jr. MAI-B } & Pearson Correlation &,$- 269(* *)$ &, 022 &,- 169 &,$- 202(*)$ & 1 &, 006 & ,034 \\
\hline & Sig. (2-tailed) &, 007 &, 831 & 093 &, 043 & & ,951 & ,739 \\
\hline & $\mathrm{N}$ & 100 & 100 & 100 & 100 & 100 & 100 & 100 \\
\hline \multirow[t]{3}{*}{ YIAS } & Pearson Correlation &, 057 &,- 094 &,- 049 &,- 020 & ,006 & 1 &, 062 \\
\hline & Sig. (2-tailed) &, 571 &, 351 & 629 &, 847 & ,951 & &, 540 \\
\hline & $\mathrm{N}$ & 100 & 100 & 100 & 100 & 100 & 100 & 100 \\
\hline \multirow[t]{3}{*}{ Age } & Pearson Correlation &,- 090 &,- 058 &, 048 &,- 098 &, 034 &, 062 & 1 \\
\hline & Sig. (2-tailed) &, 374 &, 568 & 634 & ,330 &, 739 &, 540 & \\
\hline & $\mathrm{N}$ & 100 & 100 & 100 & 100 & 100 & 100 & 100 \\
\hline
\end{tabular}

* Correlation is significant at the 0.05 level (2-tailed).

** Correlation is significant at the 0.01 level (2-tailed). 


\section{Statistical Analysis}

Descriptive statistics were expressed as mean, standard deviation, maximum and minimum for the numerical variables. Pearson's correlation analysis was used to evaluate the relationship between quantitative data showing normal distribution. The level of statistical significance was predetermined to be $\mathrm{p}<0.05$.

\section{Conclusions}

The present study evaluated the association of the relationship between IA, SAD and ADHD in the sample of 100 ADHD children. Anxiety as an important persistent emotional factor,

mediates between stress internet addiction(Ye and Zheng, 2016).Previous studies show that social anxiety and internet addiction are interrelated. (Ostovar et al., 2016;
Zhu, 2017)also increases the likelihood of Internet addiction (Ren et al., 2017). The comorbidity of anxiety and ADHD can be associated with impulsivity and disinhibition and working memory problems (Schatz and Rostain, 2016).In a study, Internet addiction stress and social anxiety positively correlated with social class negatively (Feng , Ma , Zhong, Q.;2019). It is showed thatsocial anxiety indirectly affects internet addiction with its negative effect on relationships.

However, social anxiety has not been extensively evaluated in previous studies and these recommendations have not yet been confirmed.The evidence from this study is incompatible with the idea that IA, and SAD are also related with the comorbid ADHD . We believe that our results may improve knowledge about the use of holistic perspective in the approach to IA and comorbid disorders

\section{References}

An, J., Sun, Y., Wan, Y., Chen, J., Wang, X.,Tao, F. (2014). Associations between problematic Internet use and adolescents' physical and psychological symptoms. Journal of Addiction Medicine 8: 282-287.

Xu, J., Shen,, L., Yan, C., Hu, H., Yang, F., Wang, L., Kotha, S. R., Zhang, L.N., Liao, X.P., Zhang, J., Ouyang, F.X., Zhang, J.S., Shen, X.M. (2012). Personal characteristics related to the risk of adolescent Internet addiction: A survey in Shanghai, China. BMC Public Health. 12: 1106.

Ge, Y., Se, J., Zhang, J. (2014) Research on relationship among internet-addiction, personality traits and mental health of urban left-behind children. Glob J Health Sci. 2014;7:60-9.

Bahrainian, A., Khazaee, A..(2014). Internet addiction among students: The relation of self esteem and depression. Bull Environ Pharmacol Life Sci. 3:1-6.

Yen, J.Y., Ko, C. H., Yen, C.F., Wu, H.Y., Yang, M.J. (2007) The comorbid psychiatric symptoms of Internet addiction: Attention deficit and hyperactivity disorder (ADHD), depression, social phobia, and hostility. The Journal of Adolescent Health. 41:93-98.

Bishop, C., Mulraney, M., Rinehart, N., \& Sciberras, E. (2019). An examination of the association between anxiety and social functioning in youth with ADHD: a systematic review. Psychiatry Research, 273, 402-421.

Jarrett, M.A., and Ollendick, T.H. (2008). A conceptual review of the comorbidity of attentiondeficit/hyperactivity disorder and anxiety: implications for future research and practice. Clinical Psychology Review, 28, 1266-1280.
Ruscio, A.M., Brown, T.A., Chiu, W.T., Sareen, J., Stein, M.B., \& Kessler, R.C. (2008). Social fears and social phobia in the USA: results from the National Comorbidity Survey Replication. Psychological Medicine, 38, 15-28.

Ye, B., and Zheng, Q. (2016). The effects of stress on college student's Internet addiction. J. Psychol. Sci. 39, 621-627.

Ostovar, S., Allahyar, N., Aminpoor, H., Moafian, F., Nor, M. B. M., and Griffiths, M. D. (2016). Internet addiction and its psychosocial risks (depression, anxiety, stress and loneliness) among Iranian adolescents and young adults: a structural equation model in a crosssectional study. Int. J. Men. Health Addict. 14, 257-267.

Zhu, B. (2017). Discussion on Mechanism of Social Networling Addiction - Social Anxiety, Craving and Excitability. Dalian: Liaoning Normal University

Ren, Y., Yang, J., and Liu, L. (2017). Social anxiety and Internet addiction among rural left behind children: the mediating effect of loneliness. Iran. J. Public Health 46, 1659-1668.

Schatz, D.B., Rostain, A.L. (2016). ADHD with comorbid anxiety: a review of the current literature. Journal of Attention Disorders, 10, 141-149.

Feng, Y., Ma, Y, Zhong, Q. (2019) The Relationship Between Adolescents' Stress and Internet Addiction: A Mediated-Moderation Model. Front Psychol. Oct 4;10:2248. 